\title{
제 104회 월간 공여국 포럼 참가결과 보고
}

표제회의(104th Monthly Donor Group Forum)가 ‘6.9.19 주재국내 주요 원조공여국, 국 제기구 및 NGO 대표 등 40여명과 베트남 내무부 차관(Mr. Thang Van Phuc)이 참석한 가운데 $\mathrm{UNDP}$ 베트남 사무소 주관으로 하노이에서 개최 되어 당관에서 참석 후 그 주요 결과를 아래와 같 이 보고함.

\section{1. 회의개요}

- 일시 : 2006년 9월 19일 12:00

- 장소 : 하노이 UNDP 회의실

- 참석자 : 주베트남대사관 유연철 참사관, $\mathrm{KOICA}$ 베트남사무소 최문정부소장, 김현원 직원

- 회의주제 : 베트남 공공행정개혁(PAR : Public Administration Reform)프로그램 의 추진현황

\section{2. 회의 내용 요지}

- 표제회의는 금년 5 월 새로 부임한 UNDP사 무소 Mr. John Hendra소장의 개회사에 이 어, 주재국 내무부 Phuc 차관의 공공행정 개혁 (Public Administration Reform: $\mathrm{PAR}$ )프로그램의 성과 및 진전, 향후 과제 등에 대한 브리핑이 있었으며, 주재국측의 발표에 대해 참석자들의 질의 및 주재국의 답변 등의 순서로 진행되었음.

- 동 회의에 참석한 베트남대사관 유연철 참 사관은 한국정부는 주재국 PAR 프로그램을 지원하기 위해 다양한 $\mathrm{ODA}$ 사업을 수행해 왔음을 언급하고, 특히 올 10 월 KOICA 기술 협력사업의 일환으로 PAR관련 주재국 공무 원들의 역량 강화를 위한『베트남 공무원행 정 발전』연수 실시 예정임을 소개함. 또한, 2006-2010년 PAR 2단계 계획에서 전자정 
부(e-Government) 구축에 대한 구체적인 내용 등이 포함되어 있는 지에 대해 질의함.

- 이에 대해, Phuc 차관은 그간의 한국의 지 원에 대해 감사를 표명하고, 지난주 Asian Forum 참석차 한국을 방문한 바 있으며, 공 공부문 개혁의 노하우와 IT기술을 활용한 전자정부 구축 등의 분야에 대해 한국정부 로부터 지속적인 지원을 희망한다고 답변하 였음.

\section{3. 공공행정개혁(PAR)프로그램 추진 현황}

(주재국 내무부 차관 발표 요지)

- 베트남 정부는 2001년-2005년까지의 PAR 1단계를 평가하고 2006년-2010년의 2단계 $\mathrm{PAR}$ 프로그램을 진행 중에 있으며 관련 법 안의 개정도 진행 중임.

- $\mathrm{PAR}$ 프로그램 2 단계에서는 공공행정의 질 적 개선을 통해 공공서비스 수준을 고양시 키고, 공무원의 역량을 강화하며 관료주의 를 철폐하는 것에 중점을 두고 있음. 일례로 일부 지역을 대상으로 한 부처 및 기관에서 필요한 공공서비스를 제공받을 수 있도록 하는 'One Stop Shop Model' 을 파일럿 프 로젝트로 실시하여 확대적용 계획 중임.

- 하이퐁시를 선두로 다낭, 컨터, 롱안성 등 에서 시범적으로 실시예정
- 아울러, PAR 프로그램을 통해 베트남이 시 장경제로 전환을 실행하는 데에는 국제사회 와의 협력이 매우 중요하며 다음과 같은 부 문에서 지원이 필요함을 설명함.

- 공공행정의 변화관리제도

- 공공행정 질적 개선을 위한 제도구축

- 공무원 역량강화

- 공공행정의 현대화(투명성제고 및 전자정 부 구축 포함)

- PAR 이니셔티브 지원

- 자문위원회 그룹 구성

\section{4. 기타사항}

- 베트남대사관은 현재 반기 및 연말에 실시 되는 원조공여국회의를 중심으로 ODA관련 회의 등에 한정적으로 참여하여 왔으나 향 후 원조사업의 질적 제고 및 효과적인 Sector Approach를 위해 우리의 비교우위 가 있는 분야의 포럼 등에 우선적으로 적극 참여, 우리나라 $\mathrm{ODA}$ 사업에 대한 홍보 및 주재국내 타원조기관들과의 원조조화를 위 한 노력을 기울일 예정임. 끝.

[자료: 주베트남대사관] 